\title{
The Impact of Direct and Indirect of internal marketing on service quality and mediating role of OCB CASE: Iran Insurance Company
}

\author{
Hassan Ghorbani,Ph.D. \\ Department of Management and Accounting, Islamic Azad University \\ Mobarakeh Branch, Isfahan, Iran \\ Tell: 98-311-666-2096_E-mail: ghorbani2007ha@yahoo.com \\ Maedeh Mostafavi \\ (Corresponding Author) \\ M.A Candidate \\ Department of Management and Accounting, Islamic Azad University \\ Mobarakeh Branch, Isfahan, Iran \\ E-mail: maedeh.mostafavi@yahoo.com
}

DOI: 10.6007/IJARBSS/v3-i11/324 URL: http://dx.doi.org/10.6007/IJARBSS/v3-i11/324

\begin{abstract}
Internal Marketing is attracting, developing, motivating, and retaining qualified employees through job-products that satisfy their needs. Organizational citizenship behavior is conceptualized as synonymous with the concept of contextual performance, defined as 'performance that supports the social and psychological environment in which task performance takes place. Service quality is defined as how well the service meets or exceeds the customers' expectations on a consistent basis. The conceptual framework presented here derives from a thorough analytical and critical review of the literature on the relationship between internal marketing and the services quality, the role of organizational citizenship behaviors among internal marketing and the services quality and also the impact of internal marketing on the service quality. This study uses a Structure Equation Model (SEM) analysis to examine and measure five categories which reflect most of the employees' discretionary behaviors that can influence the customer-employee interaction facet of Service quality. The statistical population consists of customers who have used services offered by Iran Insurance Company in Isfahan. Random sampling method has been applied to select the appropriate sample. The examinations were done through 190 available questionnaires. Results based on SEM outputs demonstrate acceptance and confirmation of all studied factors. These findings indicate that Internal Marketing has a positive effect on organizational citizenship behavior, Organizational citizenship behavior has a positive effect on service quality and Internal Marketing has a positive and direct effect on service quality.
\end{abstract}

Keywords: Internal marketing; Organizational citizenship behavior; Service quality; Structure Equation Model 


\section{Introduction}

Today organizations operate in a dynamic, uncertain and challenging environment. Continuous changes and transformations in the socio-cultural conditions, as well as political upheavals, economic cycles, technological advances and changes in international relations all contribute to make the task of operating any organization successfully very daunting. Environmental dynamics and increasing Competition lead organizations to become more competitive and to be sensitive to their customers Satisfaction. (Parker et al., 1997; Schneider et al., 1998; SaraVanan and Rao, 2007).All of organizational efforts should be continued to improve and today's customer is seeking to explain that customer-oriented organizations are moving most of others towards this ideal (Rayej \& et al, 2008:67). Many companies try to review their managerial patterns and to find basic solution so that they can access to competitive advantage (Gilaninia , Ramzani \& et al, 2011; Omidvari \& et al, 2012). In a Service organization the services quality is one of the most important factors to Retain and gain new customers. In fact, in such organizations Competitive advantage, quality of service and staffing offering that service are the resources. One of the most important factors which can employ the employees' skills, attitudes and behaviorin better providing the services quality is internal marketing (Bairstow\&Skinner, 2007). Organizational citizenship behavior contains Constructive and cooperative behaviors which are not only ordered by job description but also are not rewarded directly or contractual through the official system of the organization (Awwad \& Agti, 2011). According to the mentioned issues the main questions of this research are as the following:

1. Is there any relationship between internal marketing and the services quality?

2. Do the organizational citizenship behaviors have the role of intermediate among internal marketing and the services quality?

3. Does the internal marketing have a direct impact on the service quality?

\section{Literature Review}

\subsection{Service Quality}

In the past two decades interest in SQ has strengthened as research has shown how improvements in quality can lead to improved organizational performance and competitiveness (SeyedJavadein et al., 2008; Leal and Pereira, 2003; Douglas and connor,2003).All organizations, particularly the service organizations must try to improve their SQ rapidly, because quality as the most fundamental factor brings excellent and stable competitive advantage to an organization (Bahia and Nantel, 2000). Accordingly, marketing strategy for service industries must focus on SQ (Zeithaml et al., 1996). The area of service quality is well-researched. Service quality assessments are not unidimensional (Choi, Cho,Lee, \& Choi, 2004). Service quality is defined as how well the service meets or exceeds the customers'expectations on a consistent basis (Parasuraman, Zeithaml, \& Berry, 1985). According to Bitner and Hubbert(1994), service quality is "the consumer's overall impression of the relative inferiority/superiority of the organization and its services". Unlike unlike product quality, service quality is hard to define and measure because of the inter-relationship of user expectations and the impact of specific features of service such as intangibility, inseparability, heterogeneity, and perishability (Parasuraman et al., 1985; Zeithaml, Bitner, \&Gremler, 2006).

\subsection{Organizational Citizenship Behavior}


OCB has been introduced by Organ and his colleagues in 1983 for the first time. This concept was first explained by from Barnard writings in 1983 about willingness to cooperation and also by Katz about performance and innovative behaviors in 1964, 1966 and 1978. Organ (1988) has described OCB as behaviors which are not in formal organizational functions but capable of affecting organization performance. This is an extra-role behavior, in contrast to intra-role behavior (Seyed Javadin, et al, 2012). Currently, OCB is conceptualized as synonymous with the concept of contextual performance, defined as 'performance that supports the social and psychological environment in which task performance takes place' (Organ, 1997, p. 95). While this reflects the flexible nature of workers' roles in the modern workplace, and acknowledges the fact that employees do get recognized and rewarded for engaging in OCB (Van Scotter, Motowidlo\& Cross, 2000; Werner, 1994). Currently, the most popular dimensions used to measure OCB are found in the 5 factor model (Organ, 1988):

Altruism: being helpful, Courtesy: being polite and courteous; prevent conflict, Conscientiousness: doing more than just the minimum; attention to detail (prevent/ minimize error), Civic Virtue: showing interest and involvement (e.g. keeping up to date) with the organization; defend organizational policies and practices, Sportsmanship: tolerating less-thanideal conditions; accepting of changes and performs requests without complaints

\subsection{Internal Marketing}

One of the most basic definitions of the concept of internal marketing is, according to cahill (1995) , presented by Berry and parasuraman in their book Marketing Services : competing Through Quality (1991):"Internal Marketing is attracting , developing ,motivating , and retaining qualified employees through job-products that satisfy their needs. Internal marketing is the philosophy of treating employees as customer-indeed, "wooing" employees...-and is the strategy of shaping job-products to fit human needs" (cahill, 1995). Many authors have suggested that IM is a prerequisite for external marketing (Foreman and Money, 1995; Gronroos,2000; Kotler,2000).Green et al .(1994) states that IM is the key factor to a superior and more valuable service and results in external marketing success.(Seyed Javadin, et al 2012). IM acts as a comprehensive managing process that integrates and compiles organization's multi -functionality in two directions. First, it causes all employees in all levels of organization to experience and perceive the business, its various activities and processes in the context of its operating environment. Second, it makes all employees motivated and ready to operate in a service-oriented fashion (Gronroos, 2000).

\section{Hypotheses}

Figure 1, shows research model that includes the higher-order factors of IM as well as the structure model depicting the relationships between the mixed and key outcomes. Three hypotheses are proposed regarding this model.

\subsection{The Relationships between IM and OCB}

Bansal et al (2001) have claimed that internal marketing can influences external marketing outcomes through OCBs. Souchon and Lings (2001) believe that the adoption of internal marketing practices has had an impact on citizenship behavior and employee retention. In this regard this work also examined the impact of internal marketing dimensions on OCB in addition to examining the impact of internal marketing on OCB. SeyedJavadin et al (2010) have examined the mediating role of organizational citizenship behavior in the relationship between 
internal marketing and quality of services in Tehran Gas Company. Results of research show the positive and significant impact of internal marketing on organizational citizenship behavior in the above company. Likewise Lings (2004) illustrates that considering the employees as internal market through internal marketing could improve internal aspects of organizational performance such as job satisfaction, employees' retention and employees' organizational commitment. Also Yaghoubi et al. (2011) has showed that there are positive significant relationships among internal marketing and OCB and it means that increasing or decreasing in the internal marketing causes to increase or decrease OCB. Therefore, the first hypothesis is:

H1: Internal marketing has a positive effect on organizational citizenship behavior.

\subsection{The Relationships between OCB and SQ}

In service firms, the employees who make direct contact with the customer represent the organization and produce the service (Zeithaml\&Bitner, 1996). Customer-contact employee attitude and behavior influence the consumer satisfaction and service quality (Parasuraman, 1987; Crosby \& Stephens, 1987). However, it has been found that customer-contact personnel discretional behaviors not formally prescribed by the organization do influence the quality of service delivered to the consumer (Morrison, 1996; Bienstock et al., 2003).According to Turnipseed and Rassuli (2005), OCB elements which enhance performance include: elements which add social capital, helping or altruistic elements, elements resulting with time savings or problem solving, and other elements which provide socio-emotional support by boosting morale or developing a nurturing culture .The personal interaction between the customers and the contact employee is the heart of most service experiences. More specifically, contact service employees are considered as the service, in many cases there is nothing else than the Contact employee seen as the organization through the customer's eyes i.e. they personify the firm (Roman \& Ruiz 2005). The second hypotheses is:

$\mathrm{H}$ 2: Organizational citizenship behavior has a positive effect on service quality.

\subsection{The Relationships between IM and SQ}

Berry (1981) intended that employees as internal customers of organization, viewing works as internal products. Organization should create and develop good internal products to meet the needs of internal customers, so in order to attract and retain good staff, and the staff can also provide a good quality of service to their customers. Vandermerwe and Gilbert (1989) insisted that organization should be market orientation when pursue internal service quality just like following external service quality in order to maintain the competitive advantage of enterprises. Vasconcelos (2007) argued that the external marketing strategies will be improved firstly by improving the internal marketing strategy such as developing the internal relationships between the internal customers (the employees), also by satisfying the need for the internal customers and services providers to make them satisfied and motivated (Tsai \& Tang, 2008). Therefore the third hypotheses is:

H3: Internal marketing has a positive effect on service quality. 
The framework of this study depicted in Fig1, is Based on the above literature and proposed hypothesis:

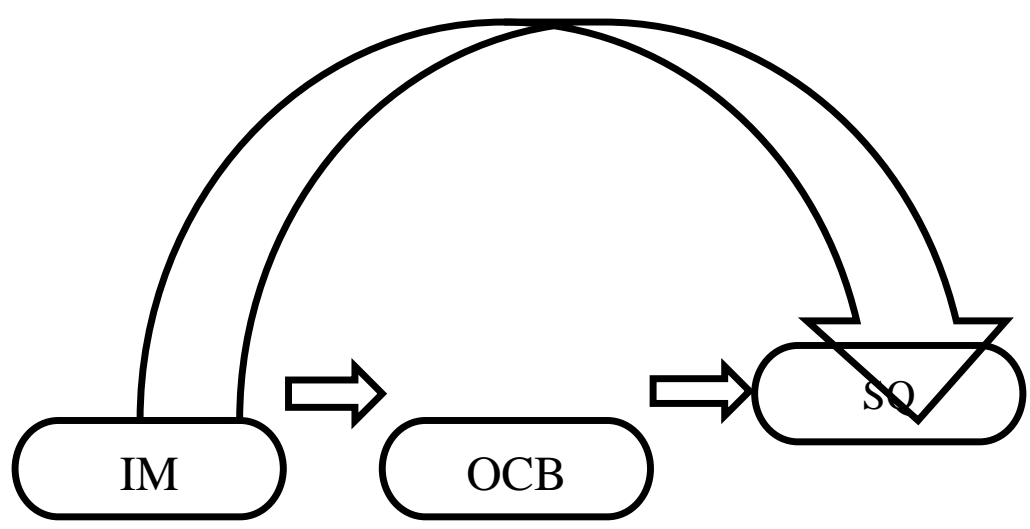

Figure1. Conceptual frame work of study

\section{Methodology}

\subsection{Sample Selection and Date Collection}

The research population contains of customers who have used Iran Insurance Company services. Random sampling method was used to have a sample of 190 respondents. A total of 180 questionnaires out of 190 were returned, demonstrating a response rate of 94 percent. Questionnaires were distributed to respondents with full instructions for completion. To ensure confidentiality of the respondents, they were asked not to give their names or any identifiable characteristics.

\subsection{Data Analysis}

In our research analysis model, IM is an exogenous variable and OCBS and SQ are endogenous variables. The distributed questionnaire is the main tool for data collection. Examining previous works (MacKenzie et al., 1991; Netemeyer et al., 1997; Posdakoff and MacKenzie, 1994) and using focus groups to identify behaviors which are evidence of OCB, five OCBs with 9 items which included altruism, sportsmanship, civic virtue, courtesy and conscientiousness were measured in this research. These five categories reflect most of employees' discretionary behaviors that can influence the customer-employee interaction facet of SQ (Yoon and Suh, 2003). Unlike most previous research, the OCB measures were acquired from employees rather than from their supervisors. The major idea of internal marketing is to apply concept of external marketing in the organization's internal market. According to this, we can propose concept of internal marketing mix. The most obvious depiction of internal marketing mix was offered by Pierce and Morgan (1991) and developed by Ahmed and Rafiq (1993). Based on Pierce and Morgan's viewpoint using of the product, price, communications and internal distribution will be leaded to facilitation of organizational change process (Piercy and Morgan, 1991). Our study measures these four dimensions for 13 items. SQ is usually measured by the SERVQUAL scale, which is based on the gap score between customer expectations and perceptions of service that Parasuraman et al. $(1988,1991)$ proposed. Dimensions of SQ and the questionnaire which was intended to measure them were customized for Iran Insurance Company services by practitioners and focus groups. Consequently, five dimensions of SQ were measured by 11 items. Considering the fact that measurement issues differ from one industry to another and also from one culture to another, and noting the fact that most of the variables in the fields of 
marketing, business and $\mathrm{OB}$ could not be observed directly and consequently cannot be measured with complete accuracy (Segars, 1997), we used structuring equation modeling (SEM) approach to measure constructs. Accurate measurements of such complex variables require careful analysis and are the building blocks for generating valid relationships among a system of variables. In this research, before testing hypotheses, suitability reliability and validity of the measurement tools were examined by utilizing confirmatory factor analysis technique and SEM. The reliability of the questionnaire was calculated by means of Cronbach alpha coefficient and estimated to be 0.87 .

Table 1.Research Measures and constructs reliability

\begin{tabular}{ll}
\hline Construct & $\begin{array}{l}\text { Cronbach's } \\
\text { Alpha }\end{array}$ \\
\hline Internal marketing & 0.90 \\
OCB & 0.852 \\
Service Quality & 0.830 \\
Total & 0.87 \\
\hline
\end{tabular}

\section{Results}

The frequency and percentage of variables such as Gender, Age and Educational status are shown in Table 4.

table 4. Sample demographic characteristics

\begin{tabular}{llll}
\hline Variable & Type & Frequency & Percent \\
\hline Gender & Male & 130 & 72.2 \\
& Female & 50 & 27 \\
Age & $21-30$ & 35 & 19 \\
& $31-40$ & 48 & 26 \\
& $41-50$ & 57 & 31 \\
Educational & High school & 40 & 22.2 \\
status & More than 50 & 25 & 13.8 \\
& Diploma & 60 & 33.3 \\
& Bachelors & 76 & 42.2 \\
& Masters and Ph.D & 19 & 10.5 \\
\hline
\end{tabular}

The validity of the constructs was determined through Confirmatory Factor Analyses. CFA on Internal marketing with 13 items (question 1 to 13), OCB with 9 items (question 14 to 22), and 
service Quality with 11 items (question 23 to 33) produced the following results, representing suitability of the measures to be used for further analysis:

Table 2. Results of the Confirmatory Factor

Analysis

chi-square $\quad 270.19$

df 132

The research $p$-value 0.09 hypotheses were tested by Structural RMSEA 0.004 Equation Analyses (SEM) using LISREL software. The structural equation modeling technique enables the simultaneous estimation of multiple regression equations in a single framework. Notably, direct and indirect relationships in the model are estimated simultaneously, and thus the method allows all the interrelationships among the variables to be assessed in the same decision context. Researchers recommend that a sample size 100 to 200 is appropriate for Structure Equation Model (SEM) analysis, (Bollen, 1989). The sample size in this study was 180 , so SEM analysis could be applied. Covariance matrices were analyzed in all cases using LISREL software. The correlation matrix of data is shown in table 5 . The result indicates chi-square is 270.19 calculated by LISREL. As degree of freedom is $132, \chi^{2} / \mathrm{df}=2.04$. Other results based on LISREL's output are:

Table 3. Fit indices for the path model

\begin{tabular}{ll} 
Goodness of Fit Index (GFI) & 0.91 \\
$\begin{array}{l}\text { Root Mean Square Error of Approximation } \\
\text { (RSMEA) }\end{array}$ & 0.004 \\
Comparative Fit Index (CFI) & 0.93 \\
Standardized Root Mean Square Residual & 0.0045 \\
(SRMR) & \\
NFI & 0.92 \\
\hline
\end{tabular}

Such results prove that the proposed model exhibits a reasonably good fit to the data. Figure 2 shows the principal model of research and figure 3 illustrates the results of the hypothesis testing. Circumstantial evidence $t$ is used to find out if proposed relationships are significant or not. This circumstantial evidence refers to the proportion of each parameter's coefficient to the standard deviation error of that parameter which will be significant when it is higher than 2 ( $t$ $\geq 2$ ) in t-test and higher than 1.96 ( $z \geq 1.96)$ in $z$-test. According to what is mentioned, following results can be extracted:

Figure2. Principal Model of Research 


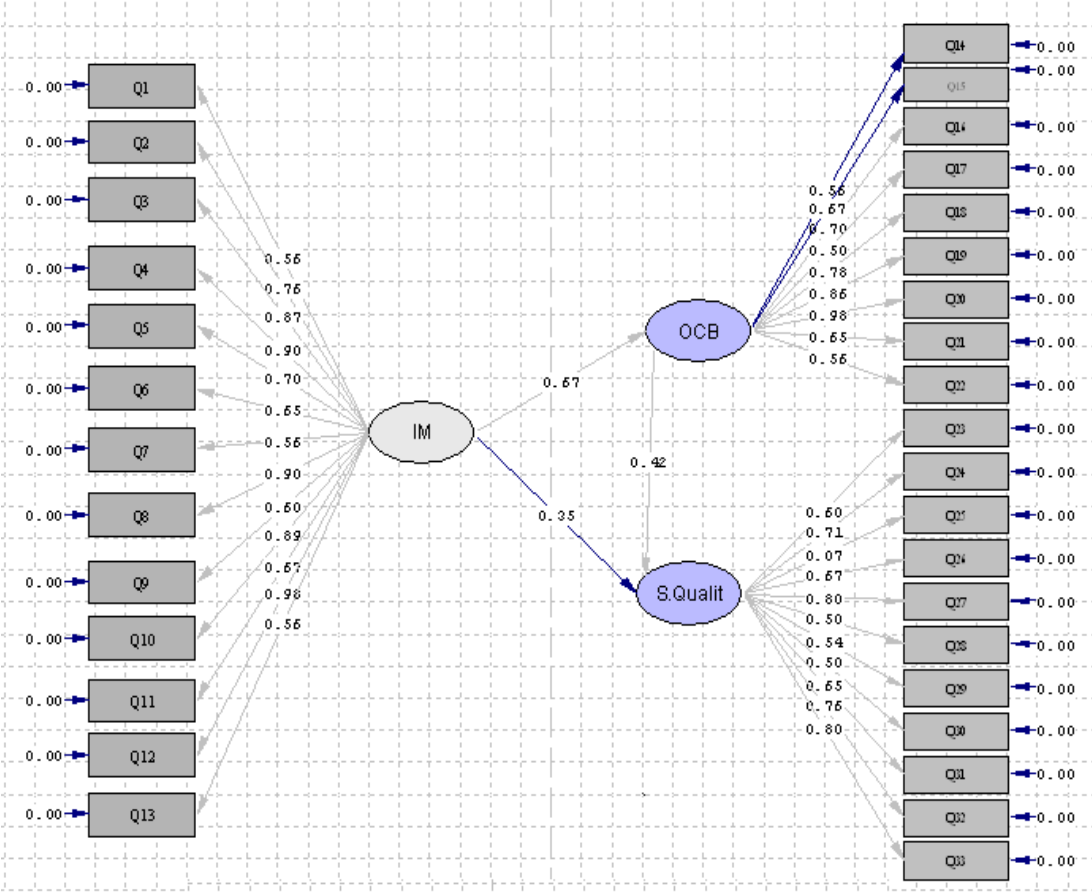

Chi-Square $=270.19, d f=132, p-v a l u e=0.09$, RMSEA $=0.004$

Figure3. Model of Adjusted Index of T

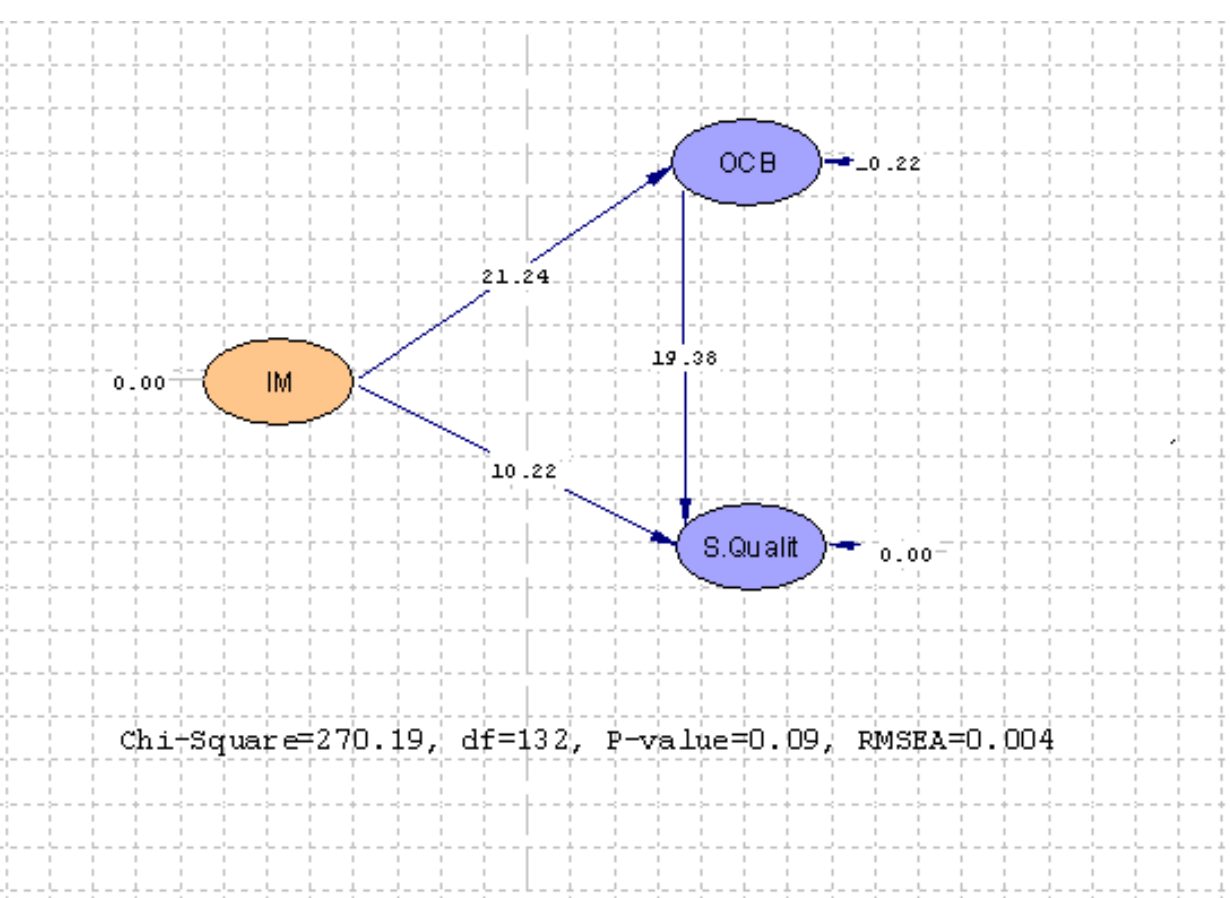

As expected in the first hypothesis, Internal marketing has a positive effect on organizational citizenship behavior $\left(\mathrm{H} 1: \gamma_{1}=0.67, \mathrm{p}<0.05\right)$, in second hypothesis Organizational citizenship behavior has a positive effect on service quality $\left(H 2: \nu_{2}=0.42, p<0.05\right)$. The third hypothesis predicted that internal marketing has a positive effect on service quality. Statistic results 
confirmed this prediction as well $\left(\mathrm{H} 3: \gamma_{3}=0.35, \mathrm{p}<0.05\right)$. Generally all of research hypotheses were confirmed statistically. The results are shown in table 5.

Table 5. Analysis of the results

\begin{tabular}{llllll}
\hline & & Hypotheses & Coefficient & T- value & $\mathrm{p}$ \\
\hline Internal marketing $\rightarrow$ & OCB & $\mathrm{H} 1$ & 0.67 & 21.2 & $<0.05$ \\
$\mathrm{OCB}$ & $\mathrm{H} 2$ & 0.42 & 19.3 & $<0.05$ \\
Internal marketing $\rightarrow$ Service Quality & Service Quality & $\mathrm{H} 5$ & 0.35 & 10.2 & $<0.05$ \\
\end{tabular}

\section{Conclusion}

This study was conducted to investigate the conceptual and empirical links between IM, extrarole behavior and SQ (Morrison, 1996; Bansal et al., 2001). This study adds to our understanding of IM and SQ and provides further evidence of the critical role that OCBs and contact employees play in ensuring high levels of customer service. Based on the data of first and second hypothesis analysis, it can be said that, there are third major conclusions about this hypothesis and that can be taken as follows; Firstly, the relationship between the organizational citizenship behavior and service quality. The findings showed that the OCB's visual and virtual variables have the positive and significant influences on service quality. The second conclusion is there are positive significant relationships among internal marketing and OCB's visual and virtual variables and it means, increasing and decreasing in the internal marketing causes to increase or decrease $\mathrm{OCB}$, and it approves that there are relationships between all the variables of this study, and According to the results of this research there is a positive and meaningful relation between internal marketing and services quality.

\section{References}

[1].Bahia, K.and Nantel, J.(2000)," A reliable and valid measurement scale for the perceived Service quality of banks", International Journal of Bank Marketing ,Vol. 18 No. 2, pp.84-91. [2]. Bansal H. S., Mendelson M. B., \& Sharma B. (2001).The impact of internal marketing activities on external marketing outcomes. Journal of Quality Management, 6(1), 61-76. [3]. Bellou, V. and Andronikidis, A., 2008, The impact of internal service quality on customer service behavior Evidence from the banking sector, International Journal of Quality \& Reliability Management, Vol. 25 No. 9, 2008 pp. 943-954.

[4]. Berry, L,L.(1981 - The employee as customer, Journal of Retail Banking, 3 (1) , 25-28. [5]. Bienstock , C. C., DeMoranville, C. W. \& Smith, R. K. (2003).Organizational citizenship behavior and service quality. Journal of Services Marketing, 17, 4, 357-378.

[6]. Bitner, M. J., \& Hubbert, A. R. (1994). Encounter satisfaction versus overall satisfaction versus quality. In Rust,R. T., \& Oliver, R. L. (Eds.), Service Quality: New directions in theory and practice (pp.72-94). London:Sage. http://dx.doi.org/10.4135/9781452229102.n3 
[7].Cahill, D.J.(1995).The managerial implications of the learning organization: A new tool for internal marketing Journal of services Market ,9,43-57.

[8]. Choi, K., Cho, W., Lee., H., \& Choi, K. (2004). The relationship among quality, value, satisfaction and behavioral intentions in health care provider choice: A South Korean study. Journal of Business Research,57, 913-921. http://dx.doi.org/10.1016/S0148-2963(02)00293-X [9]. Crosby, L.A. \& Stephens, N. (1987).Effects of relationship marketing on satisfaction, retention, and prices in the life insurance industry. Journal of Marketing Research,24, 404-11. [10]. Dimitriades , 2007, The influence of service climate and job involvement on customeroriented organizational citizenship behavior in Greek service organizations: a survey, Employee Relations Vol. 29 No. 5, pp. 469-491.

[11]. Djati, S.P. 2008. Organizational Citizenship Behavior (OCB): Variabel Anteseden dan Pengaruhnya terhadap Service Quality, Program Doktor Ilmu Manajemen, Pascasarjana Fakultas Ekonomi Universitas Brawijaya, Disertasi.

[12].Douglas, L. and Connor, R. (2003)," Attitudes to service quality-the expectations gap" ,Nutrition \& Food Science, Vol .33 No. 4,pp. 165-72.

[13].Foreman, S.K. and Money, A.H.(1995), "Internal marketing: concepts, easurement, and Application", Journal of Marketing Management, Vol. 11, pp. 755-68.

[14]. Gilaninia, Sh; Chirani,E;Ramezani ,E.(2011). The Impact of Supply Chain Management Practices on Competitive Advantage, interdisciplinary journal of contemporary research in business, ijcrb.webs.com, VOL 3, NO , p577-587.

[15].Greene, W., Walls, G. and Schrest, L.(1994)," Internal marketing : the key to external Marketing success", Journal of Service Marketing, Vol. 8 No. 4, pp. 5-13.

[16]. Gronroos, C.(2000), Service Management and Marketing: A Customer Relationship Management Approach, 2 nd ed., Wiley, New York, NY.

[17]. Herington et al. (2006).Internal Relationships-Linking practitioner literature and relationship marketing theory in Lombard, M. (2010). Employees as customers-An internal marketing study of the Avis car rental group in South Africa, African Journal of Business Management, 4(4), 362-372.

[18].Kotler, P. (2008). Marketing Management (13th ed.). New Jersey: Prentice Hall. [19].Kotler , P.(2000), Marketing Management, The Millennium Edition, Prentice-Hall, London. [20].Lai, F., Griffin, M., and Babin, B.J., 2009, How quality, value, image, and satisfaction create loyalty at a Chinese telecom, Journal of Business Research 62, pp. 980-986.

[21].Leal, R.P .and Pereira, Z.L. (2003), "Service recovery at a financial institution", International Journal of Quality \& Reliability Managment ,Vol.20 No. 6,pp. 646-63.

[22]. Little, A. B., \& Little, D. W. (2009). The 'Home Team' approach to service quality: Linking and leveraging communciations between human resources, operations and marketing. Journal of Organizational Culture, Communications \& Conflict, 13(2), 57-70.

[23].Mohammad Suleiman Awwad\&Djouhara Ali mohammadAgti (2011), The impact of internal marketing on commercial banks market orientation, International journal of Bank marketing(2011) Organizational Homoeostasis:A Role for internal marketing(1992) MCB [24].Morrison, E. (1996).Organizational citizenship behavior as critical link between HRM practices and service quality. Human Resource Management, 35, 493-512. 
[25].Omidvari,N;Gilaninia,Sh;Mousavian,S.J;Bakhshipour,A;Bakhshipour,A;Eftekhari,F.(2012). The Role Of ICT In Performance Of Small And Medium Enterprises, Interdisciplinary Journal Of Contemporary Research In Business, VOL 3, NO 9, Pp833-839.

[26].Organ, D. W. (1997). Organizational citizenship behavior: It's construct clean-up time.Human Performance, 10(2), 85-97. doi: 10.1207/s15327043hup1002_2

[27].Organ, D. W. (1988). Organizational citizenship behavior: The good soldier syndrome .USA: D.C. Heath and Company.

[28].Parasuraman, A., Zeithaml, V. A., \& Berry, L. (1985). A conceptual model of service quality and its implications for future research. Journal of Marketing, 49(4), 44-48.

http://dx.doi.org/10.2307/1251430

[29].Parasuraman, A. (1987). Customer-oriented corporate cultures are crucial to services marketing success. Journal of Services Marketing, 1, 1, 39-46.

[30].Parker, S.K., Wall, T.D. and Jackson, P.R. (1997)"'That's not my job: developing flexible Employee work orientations", Academy of Management Journal, Vol. 40, pp.899-929 [31].Saravanan , R. and Rao, K.S.P. (2007),"Measurement of service quality from the customer's Perspective - an empirical study ", Total Quality Management \& Business Excellence,Vol.18No.18 No. 4, pp.435-49.

[32].Schneider, B., White, SS. and Paul, M.C. (1998), "Linking service climate and customer Perceptions of service quality: test of a causal model", Journal of Applied Psychology, Vol. 83, pp. 150-63.

[33].Seyed Javadein ,S.R.,Khanlari, A. and Estiri, M. (2008), "Customer loyalty in the sport services industry: the role of service quality, customer satisfaction, commitment and trust", International Journal of Human Sciences, Vol. 5 No. 2, pp.1-19.

[34].SeyedJavadin, S.R., Rayej, R., Yazdani H., Estiri M.,Aghamiri S.A(2012),"How Organizational citizenship behavior mediates between internal marketing and service quality", International Journal of Quality \& Reliability Management, Vol. 29 No. 5, pp.3-5

[35]. Souchon, A., and Lings, I. (2001). Adopting internal marketing practices across national borders: key propositions and implications, pp. 1-9

[36]. Tsaia Y., \& Tang Ta-Wei. (2008). How to improve service quality: Internal marketing as a determining Factor. Total Quality Management, 19(11), 1117-1126.

http://dx.doi.org/10.1080/14783360802323479

[37]. Turnipseed, D.L., Rassuli, A., 2005. Performance perceptions of organizational citizenship behaviors at work: a bi-level study among managers and employees. British Journal of Management, 16, 231-244.

[38].Vandermerwe, S.,Gilbert, D. J. (1991) - Internal service: gaps in needs/performance and prescriptions for effectiveness. International Journal of Service Industry Management ,2,50-60.

[39].Van Scotter, J. R., Motowidlo, S. J., \& Cross, T. C. (2000).Effects of task performance and contextual performance on systemic rewards. Journal of Applied Psychology, 85(4), 526-535. doi: 10.1037//0021-9010.85

[40].Wallace, E., Chernatony, L., and Buil, I., 2011, Within-role, extra-role and anti-role behaviors in retail banking, International Journal of Bank Marketing, Vol. 29 No. 6, pp. 470-488. 
[41].Werner, J. M. (1994). Dimensions that make a difference: Examining the impact of in-role and extra role behaviors on supervisory ratings. Journal of Applied Psychology, 79(1), 98-107. [42].Yaghoubi , N. M.; Salehi, M. and Moloudi, J. (2011).Improving service quality by using organizational citizenship behavior: Iranian evidence.Iranian Journal of Management Studies (IJMS). Vol.4, No.2, pp: 79-97.

[43].Zeithaml, V.A., Berry , L.L. and Parasuraman ,A. (1996)," The behavioral consequences of Service quality", Journal of Marketing ,Vol. 60,pp. 31-46.

[44].Zeithaml, V. A., Bitner, M. J., \& Gremler, D. D. (2006). Service management: Integrating customer focus across the firm. New York: McGraw-Hill.

http://dx.doi.org/10.1177/0092070300281007

[45].Zeithaml, V. A. \& Bitner, M. J. (1996).Services Marketing, McGraw-Hill, New York, NY. 